American University Washington College of Law

Digital Commons @ American University Washington College of

Law

Articles in Law Reviews \& Other Academic Journals

Scholarship \& Research

2013

\title{
In Defense of Scholars' Briefs: A Response to Richard Fallon
}

Amanda Frost

American University Washington College of Law, afrost@wcl.american.edu

Follow this and additional works at: https://digitalcommons.wcl.american.edu/facsch_lawrev

Part of the Constitutional Law Commons, International Law Commons, Legal Education Commons, Legal Ethics and Professional Responsibility Commons, and the Legal History Commons

\section{Recommended Citation}

Frost, Amanda, "In Defense of Scholars' Briefs: A Response to Richard Fallon" (2013). Articles in Law Reviews \& Other Academic Journals. 1383.

https://digitalcommons.wcl.american.edu/facsch_lawrev/1383

This Article is brought to you for free and open access by the Scholarship \& Research at Digital Commons @ American University Washington College of Law. It has been accepted for inclusion in Articles in Law Reviews \& Other Academic Journals by an authorized administrator of Digital Commons @ American University Washington College of Law. For more information, please contact kclay@wcl.american.edu. 


\title{
$\xi \beta$ \\ IN DEFENSE OF SCHOLARS' BRIEFS \\ A RESPONSE TO RICHARD FALLON
}

\author{
Amanda Frost
}

I

N A THOUGHTFUL AND PROVOCATIVE ESSAY, Richard Fallon criticizes law professors for lightly signing on to so-called "scholars' briefs," that is, amicus briefs filed on behalf of a group of law professors claiming expertise in the subject area. ${ }^{1}$ Fallon argues that law professors are constrained by ethical obligations from joining such a brief without first satisfying standards similar to those governing the production of scholarship, and he believes that law professors should sign onto fewer briefs than they currently do. His essay has received considerable attention in the press and from law professors, most of it positive. ${ }^{2}$ I applaud Fallon for raising the

\footnotetext{
Amanda Frost is a Professor of Law at the American University Washington College of Law. Copyright (C) 2103 Amanda Frost.

1 Richard H. Fallon, Jr., Scholars' Briefs and the Vocation of a Law Professor, 4 J. LEGAL ANALYSIS 223 (2012).

2 See, e.g., Adam Liptak, Friend-of-Court Filings Mushroom, and a Law Professor Takes Issue, N.Y. Times, Nov. 14, 2011, at A23; Michael C. Dorf, Scholars' Amicus Brief Controversy Reflects the Evolving Relationship Between the Bench and the Legal Academy, available at verdict.justia.com/2011/11/21/scholars\%e2\%80\%99-amicus-brief-controversy-ref lects-the-evolving-relationship-between-the-bench-and-the-legal-academy ("I have no gripe with the substance of what [Fallon] wrote .... As I told Liptak for the Times story, I admire Fallon's high standards.”); Paul Horwitz, Fallon, Amicus Briefs, and the Health Care Litigation, available at prawfsblawg.blogs.com/prawfsblawg/2011/11/
} 
issue, but I disagree with significant aspects of his argument.

This response begins with a brief overview of Fallon's arguments in favor of constraining law professors from participating in scholars' briefs. Part II describes my own views regarding the ethical standards that apply to scholars' briefs and then discusses the benefits to the bench and the academy of scholars' briefs that meet these standards. I conclude by explaining why I do not believe that scholars' briefs need to satisfy the standards that apply to legal scholarship.

\section{I. \\ The Case Against Scholars' Briefs}

$\mathrm{F}$ allon's essay is timely. As he points out, scholars' briefs have proliferated in recent years, with such briefs filed in more than a third of the Supreme Court's cases in the 2010 Term. ${ }^{3}$ Not much has been written about the potential conflicts between the law professor's role as scholar on the one hand, and as advocate for specific political or legal outcomes on the other. ${ }^{4}$ The practice deserves closer scrutiny, and Fallon's essay provides a well-laid foundation on which to start the debate.

Fallon's essay is thorough and thoughtful, and I cannot do its 37 pages justice in this brief overview. I therefore urge readers to read his essay first, rather than relying on my summary of his position. Nonetheless, I hope this Part contains a fair rendition of Fallon's critique of the current state of affairs with regard to scholars' briefs to set the stage for the counter-arguments that follow.

Fallon's objection to scholars' briefs is a serious one. He argues that law professors who sign such briefs "attempt to leverage their credibility as teachers and scholars to influence non-scholarly audiences, sometimes for personal gain and sometimes without satisfying the standards on which their scholarly reputations depend." Recent

fallon-amicus-briefs-and-the-healthcare-litigation.html ("Most law professors, I would guess, are inclined to agree with Fallon's recommendations in principle.”).

3 See Fallon, supra note 1, at 224.

${ }^{4}$ See id. at 227-28 (noting the dearth of literature on this subject).

${ }^{5}$ Id. at 228. 


\section{In Defense of Scholars' Briefs}

surveys of judges, justices, and law clerks suggest that scholars' briefs are given closer attention than other amicus curiae briefs because they are viewed as “'offer[ing] an informed legal analysis of a pressing legal question from a relatively neutral perspective." " In short, such briefs carry an "implied warranty of scholarly integrity" that these decisionmakers rely upon when deciding hard cases, and yet they often fail to satisfy the standards that govern legal scholarship.

Fallon provides several examples of scholars' briefs that he felt morally obligated not to join. For instance, Fallon refused to sign a brief authored by Professor Michael Dorf about an issue in Fallon's field of expertise because he was unfamiliar with a significant number of the cases cited in it. ${ }^{8}$ Fallon also declined to sign a brief by Professor Barry Friedman that made reasonable arguments about the constitutionality of the Affordable Care Act, but left out competing arguments that cut in the other direction. ${ }^{9}$ Fallon explained that he would also object to signing a brief that relied on a precedent he thought wrongly decided, or that used a theory of interpretation that he rejects, at least without inserting a caveat explaining his actual views on those questions. ${ }^{10}$ As Fallon well knows, many law professors sign scholars' briefs in such circumstances without any hesitation. This is the practice to which he objects.

Fallon is particularly concerned that, in the absence of scholarly rigor, law professors may allow themselves to be swayed by their ideological preferences into signing onto briefs that mischaracterize

${ }^{6}$ Id. at 225 (quoting Linda Sandstrom Simar, An Empirical Analysis of Amici Curiae in Federal Court: A Fine Balance of Access, Efficiency, and Adversarialism, 27 Rev. Litig. 669, 698-99 (2008)).

7 Id. at 228 .

${ }^{8}$ See id. at 231 ("The sole ground for my hesitation in pronouncing the brief to be simply exemplary in all respects is that it relied on so many cases. Of the dozens of Supreme Court decisions to which the brief referred, there were some that I know well, but others that I recall only hazily at best. The brief also cited at least nine Supreme Court cases that I cannot remember ever having read at all, and 12 lower court decisions that I know I have never read.”).

9 See id. at 231-33.

${ }^{10}$ See id. at 259. 


\section{Amanda Frost}

the law. He writes that the "best or correct resolution of a legal issue depends partly on how the result would cohere or fail to cohere with a sometimes intricate network of existing authorities." 11 Although Fallon acknowledges that ideology inevitably influences legal analysis, he is concerned that law professors often fail to give the proper weight to legal precedent and other authority when signing scholars' briefs. ${ }^{12}$

To avoid this possibility, Fallon argues that when a law professor signs onto briefs in her role as scholar, rather than as an advocate for one of the parties, she should consider herself bound to the same norms that govern the production of scholarship. Fallon breaks these norms down into three categories. First, a professor should assume individual responsibility for a scholars' brief in much the same way she assumes responsibility for the content of papers published under her name, meaning that she should engage in independent research to ensure that the claims in the brief are supported by the authorities cited. Second, a professor should only join a scholars' brief if she sincerely believes all of its claims and arguments, which he labels the scholarly norm of trustworthiness. Finally, a professor should ensure that any scholars' brief she joins satisfies the norm of confrontation, meaning that it candidly addresses significant objections to its analysis. ${ }^{13}$

Fallon concedes that these norms need some tweaking to take into account the constraints on legal briefs. For example, he acknowledges that due to page limitations, a scholars' brief cannot raise and address every objection to the thrust of its argument, necessitating modification of the scholarly norm of confrontation. ${ }^{14}$ Nonetheless, he argues that scholars signing onto briefs should adhere to the norms of individual responsibility, trustworthiness, and confrontation as closely as possible within the limits of the form.

Fallon is well aware that doing so would reduce the number of scholars' briefs as well as the number of signatories on such briefs,

\footnotetext{
${ }^{11}$ Id. at 229.

${ }^{12}$ Id. at 229-30, 256.

${ }^{13}$ See id. at 242.

${ }^{14}$ Id. at 255.
} 


\section{In Defense of Scholars' Briefs}

and might alter the content of those that are filed. Indeed, this is one of Fallon's goals in authoring his essay. He thinks law professors should "say no" to joining such briefs "much more frequently than many of us now do," and that those briefs that professors do agree to join should "reflect higher norms of scholarly integrity than many such briefs now satisfy." 15

\section{II. \\ THE BENEFITS OF SCHOLARS' BRIEFS}

his Part describes my view of the ethical obligations that con-
strain scholars' briefs - obligations that exceed those that apply to the lawyer filing a brief for a client, but which do not require the brief to meet the norms of scholarship. This Part then explains why such briefs can benefit both the bench and the academy.

\section{A. The Ethical Standards for Filing Scholars' Briefs}

Cholars' briefs can serve a valuable role, both by helping judges decide hard cases and by creating a connection between the academy and the practice of law. To serve those dual purposes, the signatory to a scholars' brief must satisfy higher standards than those that apply to a practicing lawyer authoring or signing a brief on behalf of a client. Specifically, a scholar should only sign a brief if she: 1) is an expert in the area of law addressed in the brief; 2) has no financial interest or personal stake in the case; and 3) concludes that the arguments made in the brief are reasonable and support an outcome that the professor sincerely believes to be the best possible in light of real world constraints - by which I mean the limited space and time to make such arguments, as well as constraints posed by existing positive law and legal precedent. ${ }^{16}$

In contrast, practicing lawyers may ethically sign briefs in areas of law in which they can claim no special expertise, and on behalf of

${ }^{15}$ Id. at 227.

${ }^{16}$ The third requirement flows naturally from the first two, because a disinterested expert will only sign a brief if she thinks it is reasonable and agrees with the results it advocates. 
clients that pay them to do so. Although the brief cannot be frivolous or malicious, the practicing lawyer has no ethical obligation to agree with the argument that he is making. Thus, these three requirements of expertise, disinterestedness, and sincerity are significant additional ethical constraints on academics who author and sign scholars' briefs.

However, I do not believe that academics are ethically constrained to sign only those scholars' briefs that satisfy scholarly norms as defined by Fallon. That is, I contend that a law professor has acted ethically by signing onto a brief under the criteria described above, even if she did not engage in independent research, and even if the brief does not acknowledge all significant competing objections to its arguments. Nor do I think she must believe that all claims and arguments in the brief are "the best or correct resolution of [the] legal issue," in large part because an effective brief must work within the constraints of positive law and precedent that also constrain the court with which the brief is filed.

\section{B. The Benefits of Scholars' Briefs}

efore discussing my bases for disagreeing with Fallon in more
detail, it is worth examining whether scholars' briefs have any value if they do not meet the standards for legal scholarship. As Fallon points out, scholars join such briefs not as interested citizens but as legal academics, thereby claiming a special status from which to advise judges on the meaning of law. ${ }^{17}$ Is there any basis for making this claim if the briefs themselves are not imbued with the attributes of legal scholarship?

I see several reasons for valuing such briefs. First, applying my criteria, law professors should only author or sign briefs if they are experts in the subject. Unlike the average appellate lawyer, who is a generalist and thus might write an amicus brief in an area which she knew nothing about before taking on the assignment, law professors devote their lives to teaching and writing in specific areas of the law, and oftentimes have practiced in that area as well. It is fair to say

\footnotetext{
${ }^{17}$ See Fallon, supra note 1, at 228.
} 


\section{In Defense of Scholars' Briefs}

that the average law professor has a deeper understanding of the law governing an issue in an amicus brief than does the average lawyer writing such an amicus brief on behalf of a paying client. In at least some cases, courts will benefit from this expertise. ${ }^{18}$

Second, scholars are uniquely disinterested, in that they have no financial or personal stake in most litigation. They are not submitting the brief on behalf of a paying client, or to promote the agenda of a particular organization, or to satisfy a professional obligation. The job of law professor does not require writing or signing onto such briefs, and many never do so. ${ }^{19}$ Thus, law professors have no reason to author or join such briefs unless they sincerely support the result advocated for in the brief, and think a reasonable argument can be made for that result. These factors set scholars' briefs apart from most amicus briefs, and make them at least a shade more credible. For example, a lawyer working for an anti-death-penalty group might author an amicus brief opposing the death penalty in every single case before the Supreme Court on that subject. In contrast, a law professor who believes that the death penalty is unconstitutional might choose to participate in only those cases in which the legal arguments against capital punishment are particularly strong.

At least a few scholars' briefs have provided significant assistance to the Supreme Court in resolving difficult cases for just these reasons. Perhaps the best example is the amicus brief filed in Romer $v$.

${ }^{18}$ I am not claiming that most scholars' briefs have a significant influence on the outcome of the cases in which they are submitted. However, here is some evidence that amicus briefs generally benefit the parties they support. See Joseph D. Kearney \& Thomas W. Merrill, The Influence of Amicus Briefs on the Supreme Court, 148 U. Pa. L. Rev. 743, 830 (2000). In addition, the surveys and studies cited by Fallon suggest that scholars' briefs carry at least a little added weight with some law clerks and judges. See Fallon, supra note 1, at 225-26.

${ }^{19}$ Nor is there any reason to think that signing onto an amicus brief enhances a professor's status in the academy. Scholars' briefs are rarely read or discussed by legal academics as they would legal scholarship, and are rarely included as material to be reviewed for tenure or promotion. Although professors will often note that they have authored such briefs on their curriculum vitae, I have not seen a professor list her decision to join in such a brief on any publicly available document describing her accomplishments. 
Evans by constitutional law Professors Laurence Tribe, John Ely, Gerald Gunther, Philip Kurland, and Kathleen Sullivan. ${ }^{20}$ That brief provided a different rationale for striking down a Colorado statute than was offered by the parties - a rationale that persuaded a majority of the Court. ${ }^{21}$ The signatories to that brief had well-deserved reputations as pre-eminent authorities on constitutional law. They had no personal or financial stake in the case and were submitting the brief on their own behalf, and not that of a client. Thus, the Justices could rely on their brief as presenting sincere and reasonable arguments. If the brief were written by a concerned citizen, a gayrights group, or a lawyer on behalf of a paying client, it would likely have carried less weight.

In addition to serving the interests of judges, scholars' briefs benefit the academy. Law professors are often derided for producing highly theoretical scholarship that has no connection to the practice of law. Indeed, Chief Justice Roberts recently stated: "What the academy is doing, as far as I can tell, is largely of no use or interest to people who actually practice law." ${ }^{22}$ Likewise, law schools are frequently criticized for failing to adequately train their students to be practicing lawyers. ${ }^{23}$ When a scholar writes or signs onto an amicus brief, he must bring his scholarship down to earth, translating his perhaps quite theoretical views of how the law should be interpreted into concrete arguments that might actually succeed in persuading a court.

The authors as well as the signatories of scholars' briefs benefit from this exercise. Connecting theory and practice in this way should inform a law professor's scholarship and teaching, reminding the law professor that he is part of a professional school that must ul-

${ }^{20} 517$ U.S. 620 (1996).

${ }^{21}$ See Jeffrey Toobin, Supreme Sacrifice, New Yorker, July 8, 1996 (discussing Tribe's influential amicus brief).

${ }^{22}$ Adam Liptak, Keep the Briefs Brief, Literary Justices Advise, N.Y. Times, A12 (May 20, 2011). See also Harry T. Edwards, The Growing Disjunction Between Legal Education and the Legal Profession, 91 Mich. L. Rev. 34 (1992).

${ }^{23}$ See, e.g., David Segal, What they Don't Teach Law Students: Lawyering, N.Y. Times, A11, Nov. 19, 2011. 


\section{In Defense of Scholars' Briefs}

timately justify itself by serving the profession. Indeed, it is partly for this reason that I reject Fallon's view that a scholars' brief must maintain some of the purity of scholarship. I see value in that purity, but I also see value in recognizing the need to abandon purity for expediency when authoring an amicus brief that hopes to persuade a judge deciding a concrete case.

\section{III. \\ DISTINGUISHING SCHOLARS' BRIEFS FROM SCHOLARSHIP}

s explained in Part II, I believe that signatories to a scholars'
brief must be disinterested experts who carefully read the brief and are satisfied that it contains reasonable arguments and advocates for a result that they support. Beyond this, however, Fallon and I part ways, for I do not believe that scholars' briefs must satisfy standards similar to those that govern scholarship.

A concrete example illustrates the difference in our perspectives. Fallon argues that the norm of trustworthiness requires that a professor make explicit when any argument in a brief is at odds with that professor's purest beliefs about the law. So, for example, a law professor who believes that the death penalty is unconstitutional should not sign a brief that cites and relies upon precedent upholding capital punishment, even if the purpose of citing that precedent is to explain how the case before the court is distinguishable, unless the professor makes his views about the constitutional status of the death penalty clear. ${ }^{24}$ Similarly, Fallon asserts that a professor who is an originalist should not sign a brief that turns on non-originalist assumptions unless the brief explains that the professor views such assumptions as incorrect, but nonetheless is making arguments based on them in the hope of convincing the court to adopt what he believes to be the correct result in the case. ${ }^{25} \mathrm{I}$ disagree that such candor is called for in a scholars' brief.

\footnotetext{
${ }^{24}$ See Fallon, supra note 1, at 259.

${ }^{25}$ Id.
} 
Furthermore, I contend that law professors may ethically sign a brief without reading, or re-reading, every authority cited in it, as long as they are experts in the area of law, have carefully read the brief, and trust the brief's author. Finally, law professors may ethically sign briefs that make reasonable arguments, even if those arguments are not the "best" arguments from a scholarly perspective, and even if some counter-arguments are omitted. ${ }^{26}$ In short, I think Fallon would not have violated the moral and ethical norms of his profession had he signed onto both Michael Dorf's and Barry Friedman's amicus briefs. ${ }^{27}$

My disagreement with Fallon can be traced back to our different perspectives on two issues, one philosophical and one practical. As a philosophical matter, I have a different understanding of the relationship between law and politics. As a practical matter, I place greater significance on the differences in form and context between an amicus brief and legal scholarship.

\section{A. Law and Politics}

lthough Fallon and I agree that judicial decisions should turn on
some combination of ideological perspective and existing legal
authority, we differ on the relative importance of the two. In my
view, the "best" or "correct" legal result sometimes cannot be sepa-
rated entirely, or even significantly, from political or ideological
preferences, particularly in close cases. Existing precedent and other
authorities usually cannot provide a clear answer to the most inter-
esting and meaningful legal questions, and thus politics inevitably
influence the interpretation of those authorities and the ultimate

${ }^{26}$ As I discuss in more detail below, see infra notes 28 to 36 and accompanying text, I find it difficult to separate out my understanding of the "best" argument from the context in which the argument is being made. In other words, the "best" argument before a court is not necessarily the "best" argument from a pure scholarly perspective.

${ }^{27}$ Of course no professor should sign a brief if he is uncomfortable with its content for any reason. Fallon has every right not to join either Dorf's or Friedman's brief, and I do not think he should feel any pressure to do so. I simply disagree that he was obligated by the ethics of his profession to refuse to sign those briefs. 


\section{In Defense of Scholars' Briefs}

result. Indeed, this is the teaching of a long line of legal realists, who observed that legal authority such as precedent and canons of interpretation, although certainly relevant to any analysis, are nonetheless indeterminate and often manipulated in the service of political goals. $^{28}$

Moreover, I believe that ideology should play a significant role in resolving close legal questions, albeit one that is limited by existing legal authority and the institutional roles of the decisionmakers involved. ${ }^{29}$ Statutes, regulations, and constitutional provisions are drafted by human beings and are intended to have real world consequences. Any approach to interpreting and applying these laws requires an understanding of these consequences, along with a view about the role of law and the role of the legal institutions responsible for administering the law. ${ }^{30}$ I see no way of extracting ideology from this endeavor, nor do I see any reason to do so. In short, there is no great divide between an ideologically preferred result and the "correct" legal result because ideological preferences can, and should, affect interpretation.

${ }^{28}$ See, e.g., Karl N. Llewellyn, Remarks on the Theory of Appellate Decision and the Rules or Canons About How Statutes are to be Construed, 3 Vand. L. Rev. 395 (1950) (describing how for each "canon" of interpretation there is a conflicting canon, which allows judges to pick and choose canons to support their preferred results); Mark Tushnet, Critical Legal Studies: A Political History, 100 Yale L.J. 1515, 1518 (1991) (describing the conclusion of many critical legal studies scholars that law is "indeterminate" and "political”).

${ }^{29}$ See, e.g., Karl N. Llewellyn, The Bramble Bush 156-159 (2d. ed. 1951) (asserting that a judge's "decency and sense” are relevant to resolving legal problems).

${ }^{30}$ See, e.g., Henry M. Hart \& Albert M. Sacks, The Legal Process: Basic ProbLEMS IN THE MAKING AND APPLICATION OF LAW 1374-80 (William N. Eskridge, Jr. \& Phillip K. Frickey eds., 1994). Hart and Sacks argued that a court "should try to put itself in imagination in the position of the legislature which enacted the measure," but "should not do this in the mood of a cynical observer," but rather should "assume" that the "legislature was made up of reasonable persons pursuing reasonable purposes reasonably." Id. at 1378. They also believed that the "whole context" of a statute should be examined to aid in interpretation, and that a court "may draw on general public knowledge of what was considered to be the mischief that needed remedying." Id. at 1379. 
Political scientists have shown that judges themselves are swayed at least as much by their ideological preferences as by legal precedent, although the two undoubtedly influence each other. ${ }^{31}$ The Supreme Court can, and often does, overrule its own precedent, ${ }^{32}$ find constitutional rights that are nowhere laid out in that document's text, ${ }^{33}$ and adopt new interpretations of long-existing statutes. ${ }^{34}$ In a world in which this is a fairly common occurrence, it seems odd to tell law professors that they should only sign the briefs that contain the "correct" result as measured primarily against "existing authorities," rather than real world consequences. ${ }^{35}$

I want to be careful not to overstate this point. Obviously, there are cases in which one's preferred outcome simply cannot be reconciled with any existing authority. Politics alone should not be allowed to dictate the answer to legal questions, either for law professors writing amicus briefs or for judges deciding cases. ${ }^{36}$ Accordingly, law professors should not author or sign an amicus brief that makes arguments based solely on their personal preferences, partly because such a brief would be a waste of everyone's time, and partly because law professors should not make arguments they know have

${ }^{31}$ See, e.g., Jeffrey Segal \& Harold Spaeth, The Influence of Stare Decisis on the Votes of the United States Supreme Court Justices, 40 Amer. J. Pol. Sci. 971 (1996); Donald Songer \& Stefanie Lindquist, Not the Whole Story: The Impact of the Justices' Values on Supreme Court Decision Making, 40 Amer. J. Pol. Sci. 1049 (1996); CASS R. SunStein et al., Are Judges Political? An Empirical ANalysis of the Federal JUDICIARY (2006).

${ }^{32}$ See, e.g., Citizens United v. FEC, 130 S. Ct. 876, 912 (2010) (overruling Austin v. Michigan Chamber of Commerce, 494 U.S. 652 (1990)).

${ }^{33}$ See, e.g., Roe v. Wade, 410 U.S. 113 (1973) (declaring that women have a constitutional right to obtain abortions).

${ }^{34}$ See, e.g., Bell Atlantic v. Twombly, 550 U.S. 544 (2007) (declaring that Federal Rule of Civil Procedure 8 requires that the claims in a complaint satisfy a "plausibility" standard).

${ }^{35}$ Fallon, supra note 1 , at 229.

${ }^{36}$ See LLEWELLYN, supra note 29, at 156-159 (explaining that although courts have "leeway" to decide hard cases due to the indeterminacy of precedent and doctrine, "courts do not and cannot simply use the leeways of doctrine as they please," but rather are "controlled by the traditions of their office"). 


\section{In Defense of Scholars' Briefs}

no basis in any external authority.

Nor do I want to mischaracterize Fallon's view. Fallon also believes that ideology has some influence on interpretation, and would not claim that a case could be decided on legal precedent alone. ${ }^{37}$ In other words, we differ in degree, but not in kind. Nonetheless, the difference is important, because it explains why I think law professors are justified in signing onto amicus briefs that contain reasonable arguments that promote normatively preferable results, even if there are competing arguments that are a better fit with existing precedent and other authorities. Indeed, the goal of such a brief might be to weaken or even abolish those authorities in the interest of moving the law in a new direction - an objective that I think is an ethically defensible goal for any law professor seeking to influence a court.

\section{B. The Role of the Amicus Brief}

s a practical matter, I believe that the differences in form and
context between amicus briefs and legal scholarship necessitate applying significantly different standards to the two. Fallon acknowledges that amicus briefs come with limitations that do not accompany scholarly work, and he alters his three scholarly norms slightly to accommodate those differences. ${ }^{38}$ I view the differences between amicus briefs and scholarly articles as more important than he does, which in turn justifies greater deviations from scholarship norms. In particular, I believe that an amicus brief must operate within the constraints of the system in which judges (and not law professors) operate. For example, it must grapple with precedent which the law professor might prefer to reject wholesale, and it must assume that the adversarial system is generally an effective way to resolve disputes. Again, these differences between us, while not large, lead to different conclusions about the obligations of a law professor when signing onto an amicus brief.

\footnotetext{
${ }^{37}$ See Fallon, supra note 1, at 230-31, 241.

${ }^{38}$ Id. at 254-57.
} 


\section{The Standards that Should Govern Scholars' Briefs}

$\mathrm{T}$ ogether, these differences lead me to conclude that law professors may ethically sign scholars' briefs without adhering to the norms of individual responsibility, trustworthiness, and confrontation that govern scholarship, or at least not to the degree that Fallon would require. I will begin with trustworthiness, because our different perspectives are most starkly visible there.

\section{Trustworthiness}

Unlike Fallon, I believe that a professor may permissibly sign a scholars' brief that relies on precedents or other authorities with which the professor disagrees, as long as those arguments are reasonable and support an outcome that the professor sincerely believes to be the best possible in light of existing constraints. To use Fallon's example, ${ }^{39}$ even if a professor holds the view that the death penalty is unconstitutional and that the precedents saying otherwise are wrong, I believe the professor may author or sign an amicus brief that relies on those very precedents to argue against the execution of a particular defendant.

This hypothetical raises the difficulty of identifying the "best" or "correct" legal analysis in any case. A professor might conclude that the death penalty is unconstitutional based on the text of the Eighth Amendment, but she cannot deny that capital punishment has been declared constitutionally permissible by the U.S. Supreme Court. ${ }^{40}$ Indeed, even if a professor sincerely believes that the death penalty violates the Eighth Amendment, she could at the same time view a district court decision holding it to be unconstitutional as incorrect, even illegitimate, in light of these Supreme Court precedents. ${ }^{41}$

${ }^{39}$ Id. at 259.

${ }^{40}$ See, e.g., Gregg v. Georgia, 428 U.S. 153 (1976) (holding that capital punishment does not violate the Eighth Amendment to the U.S. Constitution).

${ }^{41}$ Cf. Charles Fried, Impudence, 1992 Sup. Ct. Rev. 155, 192 (describing the Ninth Circuit's decision to issue multiple stays of execution in Vasquez v. Harris over Supreme Court objection, and concluding that it is "impudent" for a judge to "admit[] that his moral title to exercise authority over his fellow citizens derives 


\section{In Defense of Scholars' Briefs}

Thus, even if the professor is convinced that the correct legal result in the abstract would be to declare the death penalty unconstitutional, that professor might nonetheless conclude that the correct outcome in a particular case is that this defendant does not qualify for the penalty under the existing (albeit flawed) precedent.

Fallon suggests that a law professor in this conundrum sign such a brief only if he inserts a caveat explaining that he believes the precedent on which the brief relies is itself in error. ${ }^{42}$ But this seems unnecessary for any law professor who acknowledges that the best analysis of a legal question from a scholarly perspective may not be the correct approach for a judge constrained by precedent. When a law professor signs a scholars' brief, she is putting aside (though certainly not disavowing) one set of views about the best outcome views that she can only consider to be the "best" in a world in which she gets to rewrite precedent and ignore politics - in favor of arguments about the best outcome in light of existing limitations, whether they be limitations created by precedent, political expediency, or the current composition of the Supreme Court. In other words, there are at least two "best" views of the law, and in the context of an amicus brief what matters is the view a judge could adopt in light of the constraints on her decisionmaking.

Furthermore, as a practical matter, a brief that explicitly noted every precedent or doctrine that at least one signatory disavowed would lose its power to persuade. A justice or law clerk would likely discount a brief's careful attempt to explain how existing case law supports the result if that same brief further states that the signatories think the whole line of cases in this area were wrongly decided. The primary goal of filing such a scholars' brief is to influence the decisionmaker, and thus Fallon's suggestion comes at a high price for those who write or sign such briefs with the hope of having such an effect.

An even harder case is presented by the professor who believes

from the authority of [the] system - and yet [to refuse to] act according to its terms").

${ }^{42}$ Fallon, supra note 1 , at 259. 
that the death penalty is unconstitutional, and who also concludes that it is difficult to distinguish a particular death row inmate's case from the precedent permitting execution. In other words, the precedent provides stronger support for execution than clemency. If I understand correctly, Fallon would conclude that a law professor who signs a scholars' brief arguing that the precedent can be stretched to require sparing the life of the prisoner has violated the ethical norms of his profession. ${ }^{43}$

I disagree, because precedents are often unstable and transitory, and can be read to support a variety of results. If any reasonable argument can be made, even if it is not the best fit with the current precedent, judges can benefit from hearing that argument. Perhaps judges will be persuaded to carve out more exceptions to the death penalty, or to create greater procedural hurdles to its implementation, than the existing case law would seem to permit. ${ }^{44}$

Indeed, this situation is not-so-hypothetical. The Supreme Court has recently declared the death penalty unconstitutional for juveniles ${ }^{45}$ and the mentally incapacitated, ${ }^{46}$ despite precedent at odds with those conclusions. I do not think that law professors who joined in amicus briefs supporting those results violated their moral or professional obligations. In fact, these cases may be incremental steps that lead to the Court's eventual declaration that the death penalty is unconstitutional in all applications, and thus I can see no reason for law professors who hold that view to abstain from participating in what may be important stepping stones toward that result.

${ }^{43}$ See id. at 229 (The "best or correct resolution of a legal issue depends partly on how the result would cohere or fail to cohere with a sometimes intricate network of existing authorities.”).

${ }^{44}$ See LLEWELLYN, supra note 29, at 157 ("[A]n appellate court is free, without hesitation and apology, to make any shift in content and direction of authorities which can be worked by the semi-automatic process by which authorities just take on new light, color, shape - and wording - as they are reviewed against fresh circumstance; but that conscious reshaping must so move as to hold the degree of movement down to the degree to which need truly presses.”).

${ }^{45}$ Roper v. Simmons, 543 U.S. 551 (2005).

${ }^{46}$ Atkins v. Virginia, 536 U.S. 304 (2002). 


\section{In Defense of Scholars' Briefs}

\section{Confrontation}

The confrontation norm suffers from some of the same flaws as the trustworthiness norm. In any close case, there will be reasonable arguments on both sides of the question. Indeed, in some cases the legal authorities might provide stronger support for the opposing party. A scholars' brief should lay out all reasonable arguments for why those precedents should be overturned or distinguished, but professors should be under no special moral obligation to spell out the weaknesses in their own argument. The point of such a brief is to give a court the benefit of these experts' reasonable arguments in favor of a result that they sincerely support, not to lay out all points on either side of the question for the judge to consider. To require otherwise suggests that there is only one "correct" answer to any question, rather than several reasonable views of the law, any one of which could be adopted by a judge acting within the parameters of her role. ${ }^{47}$

Furthermore, to require a scholars' brief to include all or most of the counter-arguments to its position would distract from its primary message, and is in any case unnecessary. The adversarial process negates the need for confrontation in an amicus brief that is called for in a scholarly article. A scholarly article is expected to stand on its own. That is, a reader should be able to reach a conclusion about the author's hypothesis without needing to read other sources. The same does not hold true for an appellate brief. The judge should not reach a decision based on reading a single amicus brief, or even all the briefs supporting just one party. Rather, the judge's decision should be informed by the adversarial exchange between the parties and their amici. ${ }^{48}$ Ideally, then, all reasonable counterarguments to a scholars' brief will be raised by the opposi-

${ }^{47}$ Of course, good advocacy might require an amicus brief to anticipate and refute possible objections. My point here is not that the scholars' brief should never include counter-arguments, but rather that the author and signatories have no moral obligation to do so.

${ }^{48}$ See Stephan Landsman, Readings on Adversarial Justice: The American APPROACH TO ADJUDICATION 2 (1988). 


\section{Amanda Frost}

tion, and thus it is simply unnecessary for the scholars' brief to make those arguments for their adversary. But even if the opposing parties fail to raise objections, the fact that a scholars' brief is submitted in an adversarial context itself eliminates any moral obligation to do opposing parties' job for them.

\section{Personal Responsibility}

Nor do I believe that a professor must take the same level of personal responsibility for the content of a scholars' brief as she would for scholarly work published under her name. Of course, a professor should read the brief carefully, should only sign it if it is in an area of the law in which she is an expert, and should have good reason to trust the author to have done her homework. But I do not think that a professor must read or re-read all the authorities cited, or parse the brief to ensure that every proposition is fully and fairly supported by the authority cited for it. In other words, although a professor should be an expert in the general area of law addressed in the brief, a professor need not do more individual research than would a practicing lawyer before signing onto an amicus brief.

An amicus brief is a different animal from a scholarly article, and is understood as such, and thus the individual responsibility norm should not apply. As a signatory to a scholars' brief, I tell the world that I agree with it and that I hold myself out as someone with expertise in the area, but not that I personally wrote or researched it. By contrast, a scholarly article that bears my name is one in which I have declared myself to be both writer and researcher. Of course, this reasoning is somewhat circular. If Fallon's view takes hold in the academy, then the understanding will be that the signatories to scholars' briefs engaged in research similar to that done as scholarship. But for the time being a signature on a scholars' brief does not attest to the same level of personal involvement as does authorship of a scholarly article.

Finally, requiring more input from signatories would be difficult as a practical matter. A single brief should have no more than two or three primary authors. Any more than that becomes unwieldy, and likely diminishes the quality of the final product. Nor is it realistic to 


\section{In Defense of Scholars' Briefs}

require circulation of a brief with sufficient lead time to allow a large group of people to make extensive edits. If even one member of the group of potential signatories makes any substantive edits, then the brief will need to be re-circulated to the entire group - a situation that could go on endlessly if every member of the group insisted on such changes. Thus, if law professors followed the norm of individual responsibility for every brief they signed, they would sign far fewer briefs. I think this would be a loss, for reasons discussed in Part II.

\section{CONCLUSION}

$\mathrm{T}$ he ethical questions raised by scholars' briefs are overdue for discussion. I agree with Fallon that authors and signatories of scholars' briefs should meet different standards than practicing lawyers writing amicus briefs, such as being experts in the subject area and sincerely believing in the result the brief advocates. Although I disagree with Fallon's conclusion that scholars' briefs must satisfy standards similar to those that apply to scholarship, I am glad that he started the conversation. Because I see some value in scholars' briefs, I hope that conversation leads to more thoughtful participation in such briefs, rather than a significant reduction in an activity that keeps professors engaged with the practice of law.

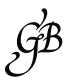

